International Journal of Agriculture, Environment and Bioresearch

Vol. 4, No. 03; 2019

ISSN: $2456-8643$

\title{
SOIL NITROGEN AND P-AVAILABLE AS AFFECTED BY BIOFERTILIZERS APPLICATION AND INORGANIC FERTILIZERS ON ANDISOLS
}

\author{
Betty Natalie Fitriatin ${ }^{1}$, Emma Trinurani Sofyan ${ }^{1}$, Anny $_{\text {Yuniarti }}{ }^{1}$ and Tien Turmuktini ${ }^{2}$ \\ ${ }^{1}$ Soil Science Department, Agriculture Faculty ofUniversitasPadjadjaran, Indonesia \\ ${ }^{2}$ Agriculture Faculty of Winayamukti University, Indonesia \\ http://doi.org/10.35410/IJAEB.2019.1115
}

\begin{abstract}
Biofertilizers are inoculants made from beneficial microorganisms that have capability to enhance the nutrient availability for plants and increase plant growth. The purpose of this research was to study the effect of biofertilizerscontaining $\mathrm{N}$-fixers and P-solubilizers and inorganic fertilizers on soil nitrogen and P-available of Andisols. This experiment used a Randomized Block Design (RBD) in factorial pattern, consisting of two factors with three replications. The first factor consisted of biofertilizers, which were ; without biofertilizers; Biofertilizers A(Pseudomonas mallei, P. cepaceae, Aspergillusniger and Penicillium sp., Azotobacter sp., Azospirillum sp.);Biofertilizer B (Azotobacterchoroococum, A. viilandii, Azospirillum, Pseudomonas cepaceae, Penicillium and Acitenobacter) and Biofertilizers A+B. The second factor were NPK fertilizers with four levels $(100 \%, 75 \%, 50 \%$ and $25 \%$ dosage of recommendation). The results showed that the application of biofertilizerscontaining $\mathrm{N}$-fixers and P-solubilizers increased soil P-available, soil $\mathrm{N}$ and fertilizer efficiency on Andisols.
\end{abstract}

Keywords: Andisols, biofertilizers, soil nitrogen and P-available.

\section{INTRODUCTION}

Chemical or inorganic fertilizers are being used to increase crop productivity and soil nutrients. However, the application of chemical fertilizers by intensive and continuous can cause adverse effects on the environment such as soil degradation. Andisol is a potential soil for planting because this soil has high organic matter content (Tan, 2008). However, Andisol has problems such as has low $\mathrm{pH}$ and low $\mathrm{P}$ availability. The low availability of $\mathrm{P}$ is due to the binding of $\mathrm{P}$ elements strongly to colloidal soil and the presence of high $\mathrm{P}$ retention $>80 \%$ (Tan, 2008). This high $\mathrm{P}$ retention results in inefficient use of $\mathrm{P}$ fertilizer. To overcome the $\mathrm{P}$ problem in Andisol, continuous handling is needed through the use of soil microbes that play a role in P. transformation.

To increase land productivity sustainably, it can be done with the application of biofertilizers and biological agents and organic ameliorants. Biofertilizers are inoculants made from active living organisms in liquid or solid forms that have the ability to mobilize, facilitate and increase the availability of non-available nutrients into available forms through biological processes.

Biofertilizers are very potential to be applied in integrated and sustainable farming systems include: $\mathrm{N}$-fixer bacteria, $\mathrm{P}$ and $\mathrm{K}$ solubilizers, plant growth promoting rhizobacteria, 
decomposers and biological agents (Singh and Purohit 2011). Phosphatesolubilizers is a soil microbial group that has the ability to extract $\mathrm{P}$ from bonds with $\mathrm{Al}, \mathrm{Fe}, \mathrm{Ca}$, and $\mathrm{Mg}$, so that it can dissolve $\mathrm{P}$ which is not available to become available for plantscalled the phosphate solubilizing microorganisms (PSM) (Withelaw, 2000). ThePSM are effective as biofertilizers in enhancing crop yields in phosphate deficient soils (Selvi, et al. 2017).

Kecskés, et al. (2016) reported that bacterial inoculations biofertilizers increased shoot and root weights of rice significantly in the greenhouse. Phosphate solubilizing microorganisms increased growth of maize and fertilizer efficiency up to $50 \%$ on Ultisols (Fitriatin, et al.,2014).Furthermore, the results of Fitriatin, et al. (2018) showed that the application of biofertilizerscontaining of Pseudomonas mallei, P.cepaceae, A.niger, Penicilliumsp, Azotobacerchroococum, Azospirilum sp. combined with humic acid increased yield of paddy rice up and reduce the dose of NPK fertilizer up to $50 \%$..

The effectiveness of biofertilizers application depends on the quality of inoculants (isolates) both as single inoculants and compound inoculants (biological fertilizer consortium), and the quality and composition of the carrier directly related to the effectiveness and viability of active ingredients (Singh and Purohit 2011). The objective of the research is to study the effect of biofertilizers containing $\mathrm{N}$-fixers and $\mathrm{P}$-solubilizers and inorganic fertilizers to enhance the soil nutrient especially soil nitrogen and $\mathrm{P}$-available.

\section{MATERIALS AND METHODS}

The pot experiment was carried out in the experimental garden of the Faculty of Agriculture, WinayaMukti University, Tanjungsari District, Sumedang West Java, Indoneisa with altitude of $856 \mathrm{~m}$ above sea levels on May-October 2018, using a $15 \mathrm{~kg}$ soil in polybag.

This experiment used a Randomized Block Design (RBD) in factorial pattern, consisting of two factors with three replications. The first factor consisted of biofertilizers, which were ;

Without biofertilizers; biofertilizers A(Pseudomonas mallei, P. cepaceae, Aspergillusniger and Penicilliumsp., Azotobactersp., Azospirillumsp.); biofertilizer B (Azotobacterchoroococum, A. viilandii, Azospirillum, Pseudomonas cepaceae, Penicillium and Acitenobacter) and biofertilizersA+B. The second factor were NPK fertilizers with four levels $(100 \%, 75 \%, 50 \%$ and $25 \%$ dosage of recommendation). The dosage of biofertilizers was $50 \mathrm{~kg} \mathrm{ha}^{-1}$ while the recommended dosage of NPK fertilizers were Urea $250 \mathrm{~kg} \mathrm{ha}^{-1}, \mathrm{SP}-36100 \mathrm{~kg} \mathrm{ha}^{-1}, \mathrm{KCl} 100 \mathrm{~kg}$ $\mathrm{ha}^{-1}$. The soil used as a planting medium for upland rice was Andisols (pH 6,1; C-org 2.90\%; NKjeldahl (0,23 \%; P- Bray 15,00 ppm; K2O 15,21 mg $\left.100 \mathrm{~g}^{-1}\right)$.Upland rice seeds using Situ Bagendit varieties.

Soil chemical properties analysed in this study were soil $\mathrm{N}$ content using Kjeldahl method and P availability using Bray I method at the end of vegetative phase.

\section{RESULT AND DISCUSSION}

Soil nitrogen content increased significantly over the control with the application of biofertilizerscontaining $\mathrm{N}$-fixers and $\mathrm{P}$-solubilizers (Table 1). These results indicate that $\mathrm{N}$-fixers (Azotobactersp. and Azospirillumsp) inbiofertilizers could increase soil $\mathrm{N}$ content through the process of fixation $\mathrm{N}$ from the air. This is in line with the results of research that Nitrogen fixing biofertiIizers mainly Azospirillumand Azotobactercan able to fix $20-40 \mathrm{~kg}$ N/ha and produce 
growth promoting substances like IAA (Essam, 2016). The composition of isolates in biofertilzers were not significantly to increase soil $\mathrm{N}$ content. However, biofertilizers consortia A(Pseudomonas mallei, P. cepaceae, Aspergillusniger and Penicilliumsp., Azotobactersp., Azospirillumsp.) provides a better increasing in soil $\mathrm{N}$ content.

Fertilization at various dosages of NPK fertilizers affects the soil N content of Andisols. Decreasing of NPK fertilizers dosage up to $50 \%$ gave soil N content werenot significantly different. This result indicate that biofertilizers can reduce inorganic fertilizers. This is supported by Kecskés, et al. (2016) reported that biofertilizers can reduce $\mathrm{N}$ fertilizers for rice.

Table 1. Soil $\mathbf{N}$ content and P-available of Andisols at the end of vegetative phase

\begin{tabular}{|c|c|c|}
\hline treatments & N-Kjeldahl (\%) & P-Bray (ppm) \\
\hline $\begin{array}{l}\text { Biofertilizers } \\
\text { - control } \\
\text { - Biofertilizers consortia A } \\
\text { - Biofertilizers consortia B } \\
\text { - Biofertilizers consortia A+B }\end{array}$ & $\begin{array}{l}0,72 \mathrm{a} \\
0,92 \mathrm{~b} \\
0,90 \mathrm{~b} \\
0,89 \mathrm{~b}\end{array}$ & $\begin{array}{l}35,75 \mathrm{a} \\
42,74 \mathrm{~b} \\
38,19 \mathrm{~b} \\
38,54 \mathrm{~b}\end{array}$ \\
\hline $\begin{array}{l}\text { NPK fertilizers } \\
-100 \% \\
-75 \% \\
-50 \% \\
-25 \%\end{array}$ & $\begin{array}{l}1,29 \mathrm{~b} \\
1,05 \mathrm{~b} \\
0,68 \mathrm{~b} \\
0,41 \mathrm{a}\end{array}$ & $\begin{array}{l}40,37 \mathrm{~b} \\
39,52 \mathrm{ab} \\
38,88 \mathrm{ab} \\
36,47 \mathrm{a}\end{array}$ \\
\hline
\end{tabular}

Note: Numerics followed by the same letters were non significant on $95 \%$ Duncan's New Multiple Range Test.

The experiment showed that biofertilizerscontaining $\mathrm{N}$-fixers and $\mathrm{P}$-solubilizerswas able to increase the P-available in Andisols (table 1). These results indicate that P-solubilizers (Pseudomonas mallei, P.cepaceae, Aspergillusniger, andPenicillium)capable to solublize $\mathrm{P}$ in Andiols. The $\mathrm{P}$ solubilizationmechanisms may involve solubilization of inorganic $\mathrm{P}$ by organic acid synthesized by P-solubilizersand mineralization of organic P by phosphatase (Lambers, etal., 2006). Previous research resultshave been known that these isolates was able to produceorganic acids and phosphatase enhance $\mathrm{P}$ solubility (Fitriatin, et al, 2014).Production of organic acidsby P-solubilizerscould form stable complexes with P-cations bonding in the soil (Sharon, et al. 2016).

The concortia of biofertilizerswere not significantly in P-available. However, biofertilizers consortia A (Pseudomonas mallei, P. cepaceae, Aspergillusniger and Penicilliumsp., Azotobactersp., Azospirillumsp.) provides a better increasing in soil P-available as same as with soil $\mathrm{N}$ content.

The various dosages of NPK fertilizers affects P-available of Andisols. Decreasing of NPK fertilizers dosage from $100 \%$ to $50 \%$ gaveP-available were not significantly. This results indicate that P-solubilizers increase fertilizer efficiency. Biswakarma, et al. (2018) reported also that phosphate solubilizing bacteria can reduce NPK fertilizers. 


\section{CONCLUSIONS}

Application of biofertilizer containing N-fixers (Azotobactersp., Azospirillumsp.) and Psolubilizers(Pseudomonas mallei, P. cepaceae, Aspergillusnigerand Penicillium) increase soil N content and P-available of Andisols. These biofertilizers can reduce NPK fertilizers up to 50\% dosage of recommendation for upland rice on Andisols.

\section{ACKNOWLEDGEMENTS}

This research work was supported by grants received (Stranas:16/UN6.E/LT/2018)) from the Directorate General of Higher Education Ministry of Research and Technology Indonesia. We are grateful to staff Laboratory of Soil Biology, Faculty of Agriculture, Universitas Padjadjaran.We are also thankful to ourstudents RobiSilpanus, Fahmi and Yusuf fromAgriculture Faculty of Winayamukti Universityfor supporting us during experiment at field.

\section{REFERENCES}

Biswakarma, B., H. Verma and N.C. Sarkar. 2018. Effect of Phosphate Solubilizing Bacteria on Yield of Transplanted Rice under Lateritic Belt of West Bengal, India. International Journal of Current Microbiology and Applied Sciences7(2): 3192-3204

Essam A. Abd El-Lattief. 2016. Use of Azospirillumand Azobacterbacteria as biofertilizers in cereal crops: A review. International Journal of Research in Engineering and Applied Sciences. 6 (7): $36 \sim 44$

Fitriatin, B.N., A. Yuniarti, and T.Turmuktini. 2014.The effect of phosphate solubilizing microbe producing growth regulators on soil phosphate, growth and yield of maize and fertilizer efficiency on Ultisol. Eurasian Journal of Soil Science.3: 104 -107.

Fitriatin, B.N., P. Tamara, O.Mulyani, E.T.Sofyan, A.Yuniarti and T. Turmuktini. 2018. Influence of biofertilizer and humic acid on NPK content and yield of rice (Oryza sativa L.). International Journal of Agriculture, Environment and Bioresearch. 3: 20-27

Kecskes, M.L., A. T. M. A. Choudhury, A. V. Casteriano, R. Deaker, R. J. Roughley, L. Lewin, R. Ford, and I. R. Kennedy. 2016. Effects of bacterial inoculant biofertilizers on growth, yield and nutrition of rice Australia. Journal of Plant Nutrition. 39 (3):377-388

Lambers, H., M.W. Shane, M. Cramer, S.J Pearse and E.J. Veneklaas. 2006. Root Structure and functioning for Efficient Acquisition of Phosphorus: Match Morphological and Physiological Traits. Annals of Botany $98: 693-713$.

Selvi, KB., JJA. Paul, V. Vijaya and K. Saraswathi. 2017. Analyzing the efficacy of phosphatesolubilizing microorganisms by enrichmentculture techniques. Biochemistry \& Molecular Biology Journal. 3 (1): 1-7 
Sharon, J,A, L.T. Hathwaik, G.M. Glenn, S. H. Imam, and C.C. Lee, 2016. Isolation of efficient phosphate solubilizing bacteria capable of enhancing tomato plant growth.Journal of Soil Science and Plant Nutrition, 16 (2): 525-536

Singh, T and S.S. Purohit. 2011. Biofertilizers Technology. Agrobios (India). ISBN. 13:978-817754-382-7.

Tan, K.H. 2008. Soils in the Humid Tropics and Monsoon Region of Indonesia.CRC Press.Taylor and Francis Group.Boca Raton London New York.

Whitelaw. 2000. Growth promotion of plants inoculated with phosphate solubilizing fungi. Adv. Agron. 69 : 99-151. 